\title{
Simultaneous Determination of Cadmium and Lead in Medicinal Plants Using Graphite Furnace Atomic Absorption Spectrometry and Direct Slurry Sampling
}

\author{
Felipe Manfroi Fortunato ${ }^{a}$, José Anchieta Gomes Neto ${ }^{a *}$, and Gian Paulo Giovanni Freschi ${ }^{b}$ \\ a São Paulo State University - Unesp, Analytical Chemistry Department \\ P.O. Box 355, 14801-970 Araraquara - SP, Brazil \\ ${ }^{b}$ Alfenas Federal University - UNIFAL-MG, Institute of Science and Technology \\ 37715-400 Poços de Caldas - MG, Brazil
}

\section{INTRODUCTION}

Phytotherapy plays a major role in the healthcare and functional food markets (1). The global market of medicinal herbs and their products is close to 62 billion dollars, and it is estimated to reach 5 trillion dollars by the year 2050 (2). The establishment of modern and accurate methods to assess the quality and to ensure the safety of medicinal plants for humans is therefore very relevant (3). Plants store nutrients in their tissues to grow healthy but they may also accumulate hazardous elements due to environmental pollution $(4,5)$.

Cadmium $(\mathrm{Cd})$ and lead $(\mathrm{Pb})$ are extremely toxic elements and normally occur at low concentrations in most plant materials (5). Thus, the determination of trace levels of $\mathrm{Cd}$ and $\mathrm{Pb}$ in real samples requires sensitive analytical methods. Among the spectrometric techniques, graphite furnace atomic absorption spectrometry (GF-AAS) offers the capability for trace analysis (6). Some of the main advantages of GFAAS are high sensitivity and selectivity, the possibility to measure several elements simultaneously, and the feasibility for direct sampling of solids or slurries (7).

Single-element determinations of $\mathrm{Cd}$ or $\mathrm{Pb}$ in plant matrices by GFAAS are largely found in the literature $(5,8)$, but only a few papers deal with direct sampling of plant

\footnotetext{
*Corresponding autbor.

E-mail: anchieta@iq.unesp.br

(J.A. Gomes Neto)

Tel: +551633019611

Fax: +551633019692
}

\section{ABSTRACT}

A method is proposed for the simultaneous determination $\mathrm{Cd}$ and $\mathrm{Pb}$ in medicinal plants using direct slurry sampling by GF-AAS The thermal behavior of analytes was checked in aqueous and slurry media using Ir permanent modifier. The optimized pyrolysis $\left(1000{ }^{\circ} \mathrm{C}\right)$ and atomization $(2200$ $\left.{ }^{\circ} \mathrm{C}\right)$ temperatures allowed calibration using aqueous standards.

For a $20-\mu \mathrm{L}$ injected volume, the calculated characteristic mass was $1.8 \mathrm{pg}$ for $\mathrm{Cd}$ and $59 \mathrm{pg}$ for $\mathrm{Pb}$. The relative standard deviation $(\mathrm{n}=12)$ for $\mathrm{Cd}$ and $\mathrm{Pb}$ was $5.3 \%$ and $3.5 \%$, respectively. The limit of detection was $0.12 \mu \mathrm{g} \mathrm{L}^{-1}$ for $\mathrm{Cd}$ and $1.22 \mu \mathrm{g} \mathrm{L}^{-1}$ for $\mathrm{Pb}$. Accuracy was checked by analyzing the standard reference materials Ginkgo Biloba Leaves, Peach Leaves, and Pine Needles. The results obtained for the analytes were in agreement with the certified values at the $95 \%$ confidence level. Ten medicinal plant samples were analyzed and the found concentrations ranged from 0.19-0.34 $\mu \mathrm{g} \mathrm{g}^{-1}$ for $\mathrm{Cd}$ and 1.02-1.91 $\mu \mathrm{g} \mathrm{g}^{-1}$ for $\mathrm{Pb}$.

slurries $(7,9,10)$. Methods involving the simultaneous determination for $\mathrm{Cd}$ and $\mathrm{Pb}$ in plants using direct slurry sampling are not described in the literature.

The main purpose of this work was the development of a simple and fast method for the simultaneous determination of $\mathrm{Cd}$ and $\mathrm{Pb}$ in medicinal plants using direct slurry sampling and GF-AAS with a transversely heated graphite atomizer and longitudinal Zeeman-effect background correction. The performance of the proposed method was checked after analyzing medicinal plant samples and three standard reference materials (SRMs).

\section{EXPERIMENTAL}

\section{Reagents and Analytical Solutions}

High purity water (resistivity $18.2 \mathrm{M} \Omega \mathrm{cm}$ ) was obtained using a Millipore ${ }^{\circledR}$ Rios 5 Reverse Osmosis $^{\mathrm{TM}}$ and a Millipore Milli- $\mathrm{Q}^{\mathrm{TM}}$ Academic $^{\text {TM }}$ system Bedford, MA, USA). Suprapur ${ }^{\circledR}$ nitric acid (Merck, Darmstadt, Germany) was employed to prepare all working solutions.

The $1000 \mathrm{mg} \mathrm{L}^{-1}$ iridium stock solution $\left(\mathrm{IrCl}_{3} \cdot 3 \mathrm{H}_{2} \mathrm{O}\right.$; Fluka $\mathrm{GmbH}$, Buchs, Switzerland) was used directly for permanent modification of the graphite furnace platform.

Five mixed analytical solutions (Cd: 0.5, 1.5, 2.5, 4.0, 5.0 $\mu \mathrm{g} \mathrm{L}^{-1}$; $\left.\mathrm{Pb}: 5.0,15,25,40,50 \mu \mathrm{g} \mathrm{L}^{-1}\right)$ were prepared daily by diluting the individual $1000 \mathrm{mg} \mathrm{L}^{-1}$ stock solutions (Merck, Darmstadt, Germany). All analytical solutions and samples were acidified to $0.14 \mathrm{~mol} \mathrm{~L}^{-1}$ $\mathrm{HNO}_{3}$. The autosampler washing solution was $0.1 \%(\mathrm{v} / \mathrm{v})$ Triton ${ }^{\circledR}$ $\mathrm{X}-100$ acidified to $0.14 \mathrm{~mol} \mathrm{~L}^{-1}$ $\mathrm{HNO}_{3}$.

All solutions were stored in Nalgene ${ }^{\circledR}$ high-density polypropylene bottles (Rochester, NY, USA). Plastic bottles and glassware materials were cleaned by soaking in $10 \%$ (v/v) $\mathrm{HNO}_{3}$ for at least 24 hours and then rinsed abundantly in deionized water before use. 
Preparation of Samples and Certified Reference Materials

Medicinal plant samples of Annona muricata, Baccharis trimera, Echinodorus grandiflorus, Equisetum arvense, Matricaria chamomilla, Melissa officinalis, Panax ginseng, Peumus boldus, Pimpinela anisun, and Mikania glomerata were purchased at a local market in Araraquara city, São Paulo, Brazil.

All samples were dried at $50{ }^{\circ} \mathrm{C}$ for 48 hours in a forced air oven and ground in a cutting mill fitted with a 20-mesh screen at the bottom of the cutting chamber. Thereafter, the samples were powdered in a Spex 6750 cryogenic mill (Metuchen, NJ, USA) using a program developed for plant materials (11). A mass of $50 \mathrm{mg}$ of samples cryogenically powdered was dispersed in $10 \mathrm{~mL}$ of $0.2 \%(\mathrm{v} / \mathrm{v})$ $\mathrm{HNO}_{3}+0.05 \%(\mathrm{v} / \mathrm{v})$ Triton ${ }^{\circledR} \mathrm{X}-100$ solution. Slurries of 3464 Ginkgo Biloba Leaves, 1547 Peach Leaves, and 1575a Pine Needles SRMs (National Institute of Standards and Technology, Gaithersburg, MD, USA) were similarly prepared.

\section{Instrumentation}

A PerkinElmer SIMAA ${ }^{\mathrm{TM}} 6000$ simultaneous multi-element atomic absorption spectrometer was used, equipped with a transversely heated graphite atomizer (THGA ${ }^{\mathrm{TM}}$ ), longitudinal Zeeman-effect background (BG) correction, and an AS-72 autosampler (PerkinElmer, Inc., Shelton, CT, USA). A PerkinElmer electrodeless discharge lamp (EDL) was used for Cd $(228.9 \mathrm{~nm})$ and a PerkinElmer Lumina ${ }^{\mathrm{TM}}$ hollow cathode lamp (HCL) was used for $\mathrm{Pb}$ $(283.3 \mathrm{~nm})$. The lamp current was $240 \mathrm{~mA}$ and $10 \mathrm{~mA}$ for $\mathrm{Cd}$ and $\mathrm{Pb}$, respectively. The atomic signals were measured in peak area mode. High-purity argon (99.99\%, White Martins, Sertãozinho, Brazil) was used as the protective and purge gas at the $250 \mathrm{~mL} \mathrm{~min}^{-1}$ flow rate.
It should be pointed out that the experiments were carried out using the stabilized temperature platform furnace, the so-called STPF conditions (12). A PerkinElmer USS-100 ${ }^{\mathrm{TM}}$ ultrasonic slurry sampler with titanium tip was used to promote homogenization of the particles during sampling (7).

\section{Analytical Procedure}

Iridium was thermally deposited onto the integrated platform of the THGA by using the features of the original software of the spectrometer. The platform was coated with $500 \mu \mathrm{g}$ Ir modifier as previously described (13).

Slurries of the samples and SRMs were transferred to autosampler cups. Immediately before sampling, the Ti ultrasound probe at $40 \%$ ultrasound amplitude was introduced into the slurries for homogenization during 10 seconds. The use of ultrasonic agitation is important to provide a uniform distribution of particles in an autosampler cup (7).

The thermal behavior of $\mathrm{Cd}$ and $\mathrm{Pb}$ was evaluated by means of pyrolysis and atomization temperature curves in order to select the optimum pyrolysis and atomization temperatures. Pyrolysis and atomization curves were built up in the following media: (a) $0.2 \%(\mathrm{v} / \mathrm{v})$ $\mathrm{HNO}_{3}$ aqueous solution containing $2.5 \mu \mathrm{g} \mathrm{L}^{-1} \mathrm{Cd}+50 \mu \mathrm{g} \mathrm{L}^{-1} \mathrm{~Pb}$, and (b) $0.5 \%(\mathrm{~m} / \mathrm{v})$ plant slurries of Ginkgo Biloba Leaves $(\mathrm{Pb})$ and Pine Needles (Cd) containing $0.2 \%(\mathrm{v} / \mathrm{v})$ $\mathrm{HNO}_{3}+0.05 \%(\mathrm{v} / \mathrm{v})$ of Triton X-100. In both situations, $20-\mu \mathrm{L}$ aliquots of samples were dispensed into the pre-treated graphite platform.

The matrix effects were evaluated by comparing the slopes of the analytical curves $\left(0.5-5.0 \mu \mathrm{g} \mathrm{L}^{-1} \mathrm{Cd}\right.$ and 5.0-50 $\left.\mathrm{g} \mathrm{L} \mathrm{L}^{-1} \mathrm{~Pb}\right)$ built up in $0.2 \%(\mathrm{v} / \mathrm{v}) \mathrm{HNO}_{3}$ aqueous solution and $0.5 \%(\mathrm{~m} / \mathrm{v})$ slurries containing $0.2 \%(\mathrm{v} / \mathrm{v}) \mathrm{HNO}_{3}+0.05 \%(\mathrm{v} / \mathrm{v})$ Triton X-100.

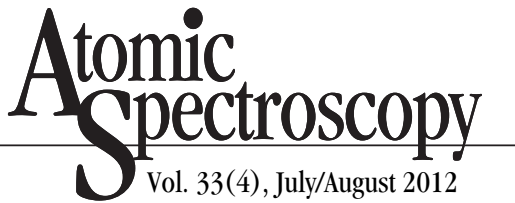

The effect of slurry amount on precision and accuracy was evaluated by analyzing slurries of Ginkgo Biloba Leaves $(\mathrm{Pb})$ and Pine Needles $(\mathrm{Cd})$ in $0.5-2.0 \%(\mathrm{~m} / \mathrm{v})$ slurries in $0.2 \%(\mathrm{v} / \mathrm{v}) \mathrm{HNO}_{3}+0.05 \%(\mathrm{v} / \mathrm{v})$ Triton X-100.

For sample analyses, aliquots of $20 \mu \mathrm{L}$ of a blank, analytical solutions, and slurries were automatically injected in sequence onto the atomizer platform by using the facilities provided by the original software of the autosampler and graphite furnace. The optimized heating program of the graphite tube is listed in Table I. All atomic absorption measurements were made at least in triplicate and based on peak area mode.

The proposed method was applied to the determination of $\mathrm{Cd}$ and $\mathrm{Pb}$ in 10 medicinal plants and three SRMs in order to assess the capability of the method in terms of accuracy and precision.

Limits of detection (LOD) and limits of quantification (LOQ) were calculated according to the IUPAC recommendations (14).

\section{RESULTS AND DISCUSSION}

Volatile elements such as Cd and $\mathrm{Pb}$ can be easily released from the graphite platform at temperatures below ca. $500{ }^{\circ} \mathrm{C}$ in the absence of a modifier (9). Direct analyses of solids or slurries usually require elaborate heating programs comprising two pyrolysis steps or airassisted pyrolysis in order to remove the matrix entirely. It should be mentioned that an airassisted pyrolysis at $600{ }^{\circ} \mathrm{C}$ was included as the first pyrolysis step (Table I) to help the complete removal of the organic matrices. And the use of permanent modifiers may help matrix removal by increasing the volatilization temperature of the analyte or by catalytic decomposition, resulting in low blank values and increased graphite 
tube lifetime. Taking into consideration the benefits mentioned above, an Ir-coated platform was selected for the direct analysis of the plants.

\section{Electrothermal Behavior}

In simultaneous determinations by GF-AAS, all analytes are similarly exposed to the single heating program of the atomizer. Consequently, the optimized pyrolysis and atomization temperatures are frequently not the best for each analyte but the most favorable to furnish required sensitivity, accuracy, and precision. The electrothermal behavior of $\mathrm{Cd}$ and $\mathrm{Pb}$ in aqueous solution and vegetal slurries using an Ir-coated platform are illustrated in Figure 1. Analysis of the figure reveals that the pyrolysis temperature reduced from $1200{ }^{\circ} \mathrm{C}$ to $1000{ }^{\circ} \mathrm{C}$ when the medium changed from aqueous to slurries, respectively. The most volatile element (Cd) defined the pyrolysis temperature at $1000{ }^{\circ} \mathrm{C}$. The atomization was fixed at $2200{ }^{\circ} \mathrm{C}$. Although these temperatures did not furnish the highest integrated absorbance for $\mathrm{Cd}$, narrow transient peaks (fast appearance and baseline restoration times) and suitable sensitivity

\section{TABLE I}

Heating Program of Atomizer for the Simultaneous Determination of $\mathrm{Cd}$ and $\mathrm{Pb}$

\begin{tabular}{ccccc}
\hline Step & $\begin{array}{c}\text { Temperature } \\
\left({ }^{\circ} \mathrm{C}\right)\end{array}$ & $\begin{array}{c}\text { Ramp Time } \\
(\mathrm{s})\end{array}$ & $\begin{array}{c}\text { Hold Time } \\
(\mathrm{s})\end{array}$ & $\begin{array}{c}\text { Argon Flow } \\
\left(\mathrm{mL} \mathrm{min}^{-1}\right)\end{array}$ \\
\hline 1 & 110 & 1 & 30 & 250 \\
2 & 130 & 10 & 30 & 250 \\
3 & 600 & 10 & 40 & 250 (air) \\
4 & 40 & 5 & 35 & 0 \\
5 & 1000 & 10 & 10 & 250 \\
6 & 2200 & 0 & 5 & 0 (read) \\
7 & 2500 & 1 & 5 & 250 \\
\hline
\end{tabular}

and precision (RSD $<2.5 \%$ for $\mathrm{Cd}$ and $<3.5 \%$ for $\mathrm{Pb}$ ) were observed.

\section{Matrix Effects}

Matrix effects were evaluated by comparing the slopes of the calibration curves built up in aqueous solution and slurries of Matricaria chamomilla, Panax ginseng, and Peumus boldus. For that sequence, good linear correlation coefficients $\left(\mathrm{r}^{2}\right)$ were obtained for $\mathrm{Cd}(0.9984$, $0.9918,0.9955,0.9951)$ and for $\mathrm{Pb}$ (0.9974, 0.9965, 0.9995, 0.9980); and the slopes of the analytical curves were $0.0329,0.0310$, $0.0339,0.0329$ (Cd) and 0.00144, $0.00150,0.00151,0.00144(\mathrm{~Pb})$.

These data expect errors of $<6 \%$ and $4 \%$ for $\mathrm{Cd}$ and $\mathrm{Pb}$, respectively, when aqueous standard calibration is used. Matrix matching or analyte addition calibrations would minimize matrix effects. However, taking into consideration that errors of $<6 \%$ are acceptable for trace analysis using direct slurry sampling, aqueous calibration is straightforward and was adopted for further studies.
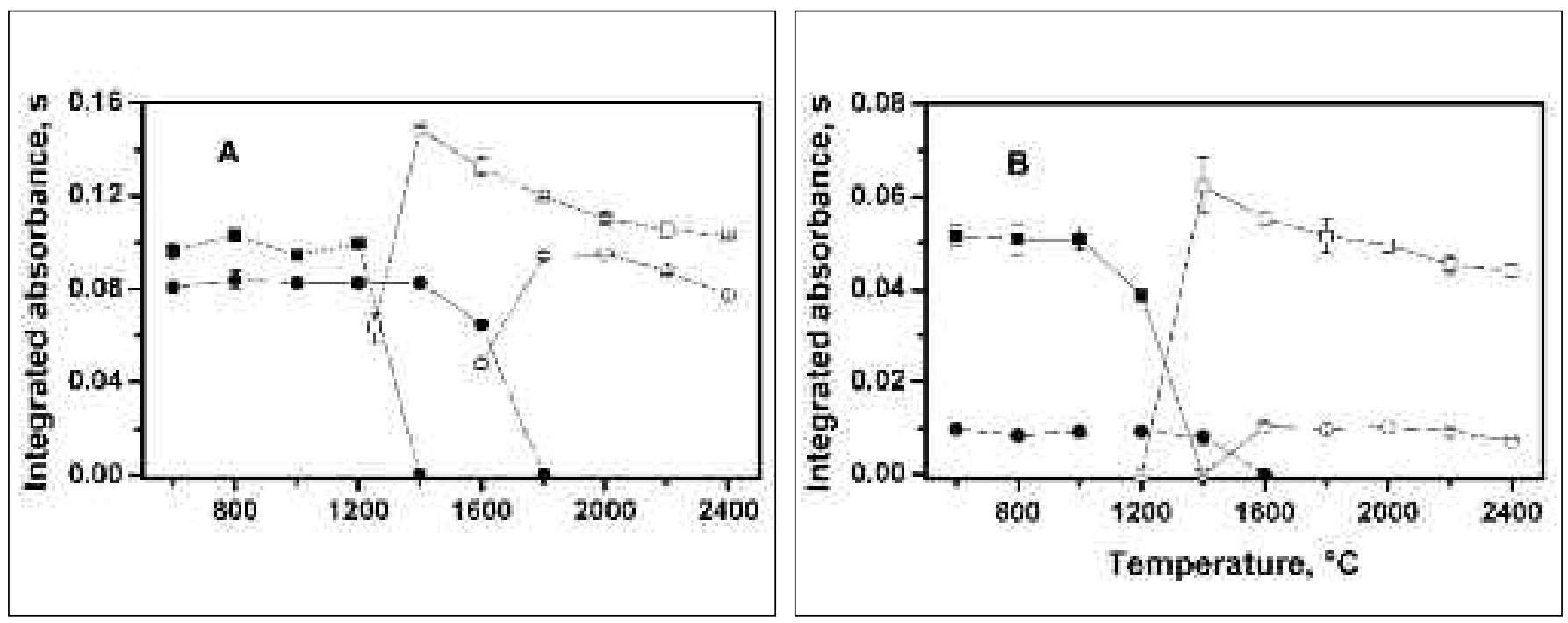

Fig 1 (A\&B). Pyrolysis (n: Cd; •:Pb) and atomization ( $\square: C d ; \bigcirc: P b)$ temperature curves in aqueous solution (A) and slurry sam-

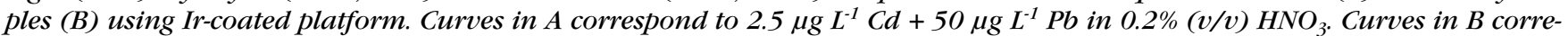
spond to $0.5 \%(\mathrm{~m} / \mathrm{v})$ slurries of Ginkgo Biloba Leaves $(\mathrm{Pb})$ and Pine Needles $(\mathrm{Cd})$ prepared in $0.05 \%(v / v)$ Triton $X-100+0.2 \%$ $(v / v) \mathrm{HNO}_{3}$. 


\section{Atomic Apectroscopy \\ 1 Vol. 33(4), July/August 2012}
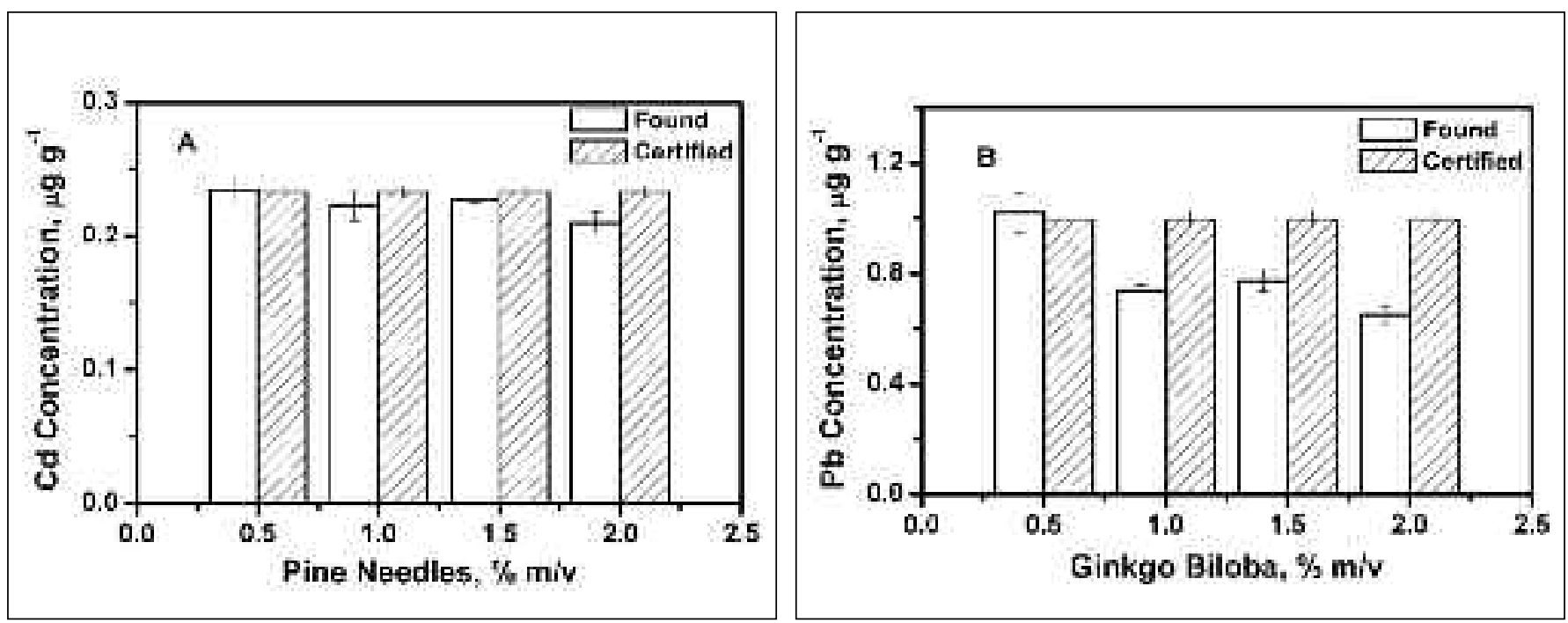

Fig 2. Influence of slurry concentration on simultaneous determination of $C d(A)$ and $P b(B)$ by GFAAS.

\section{Effect of Slurry Concentration}

Homogeneity is crucial in direct slurry sampling analysis. So, the influence of slurry concentration on accuracy was performed in the $0.5-1.5 \%(\mathrm{~m} / \mathrm{v})$ range. The results for Cd obtained in all concentrations were in agreement at the $95 \%$ confidence level (Student's $t$-test) with the certified value of the SRM Pine Needles (Figure 2A). Concentrations $>1.5 \%(\mathrm{~m} / \mathrm{v})$ produced clogging of the autosampler capillary, deteriorating sample delivery and precision. For $\mathrm{Pb}$, better results were obtained for a $0.5 \%(\mathrm{~m} / \mathrm{v})$ slurry concentration, which produced concordant results at the 95\% confidence level with the certified value of SRM Ginkgo Biloba Leaves (Figure 2B). With the aim of direct and simultaneous determination of $\mathrm{Cd}$ and $\mathrm{Pb}, 0.5 \%(\mathrm{~m} / \mathrm{v})$ slurry concentration for medicinal plants was selected.

\section{Analytical Performance}

The main figures of merit relating to the simultaneous and direct determination of $\mathrm{Cd}$ and $\mathrm{Pb}$ in slurry using an Ir-coated platform modifier were evaluated and are compiled in Table II. A $20-\mu \mathrm{L}$ volume of slurries was injected and
TABLE II

Main Figures of Merit for Simultaneous Dermination of $\mathrm{Cd}$ and $\mathrm{Pb}$ in Medicinal Plants by the Proposed Method

\begin{tabular}{|c|c|c|}
\hline Parameters & $\mathrm{Cd}$ & $\mathrm{Pb}$ \\
\hline LOD & $0.12 \mu \mathrm{g} \mathrm{L}^{-1}$ & $1.22 \mu \mathrm{g} \mathrm{L}^{-1}$ \\
\hline LOQ & $0.40 \mu \mathrm{g} \mathrm{L}^{-1}$ & $4.04 \mu \mathrm{g} \mathrm{L}^{-1}$ \\
\hline $\mathrm{m}_{0}$ & $1.8 \mathrm{pg}$ & $59 \mathrm{pg}$ \\
\hline RSD & $5.3 \%$ & $3.5 \%$ \\
\hline Slope & 0.04695 & 0.00147 \\
\hline $\mathrm{R}^{2}$ & 0.9982 & 0.9997 \\
\hline Pyrolysis temperature & & $1000^{\circ} \mathrm{C}$ \\
\hline Atomization temperature & & $2200{ }^{\circ} \mathrm{C}$ \\
\hline Injected volume & & $20 \mu \mathrm{L}$ \\
\hline Slurry & & $0.5 \%(\mathrm{~m} / \mathrm{v})$ \\
\hline Modifier & & $500 \mu \mathrm{g} \mathrm{Ir}$ \\
\hline
\end{tabular}

LOD: limit of detection; LOQ: limit of quantification; $\mathrm{m}_{\mathrm{o}}$ : characteristic mass; RSD: relative standard derivation; $\mathrm{R}^{2}$ : correlation coefficient.

the calculated characteristic mass for $\mathrm{Cd}$ was $1.8 \mathrm{pg}$ and for $\mathrm{Pb}$ was $59 \mathrm{pg}$. The relative standard deviation $(\mathrm{n}=12)$ for a sample (Melissa officinalis), containing $0.19 \mu \mathrm{g} \mathrm{g}^{-1}$ $\mathrm{Cd}$ and $1.91 \mu \mathrm{g} \mathrm{g}^{-1} \mathrm{~Pb}$, was $5.3 \%$ for $\mathrm{Cd}$ and $3.5 \%$ for $\mathrm{Pb}$. The limit of detection, calculated according to IUPAC recommendation (14), was $0.12 \mu \mathrm{g} \mathrm{L}^{-1}$ and $1.22 \mu \mathrm{g} \mathrm{L}^{-1}$ for $\mathrm{Cd}$ and $\mathrm{Pb}$, respectively. 
TABLE III

Comparative Results (Medium $\pm \mathrm{SD}, \mathrm{n}=3$ ) of the Simultaneous Determination of $\mathrm{Cd}$ and Pb in SRMs by the Proposed Method

\begin{tabular}{lcccc}
\hline SRM & $\begin{array}{c}\text { Found } \\
\left(\mu \mathrm{g} \mathrm{g}^{-1}\right)\end{array}$ & $\begin{array}{c}\text { Cd } \\
\left(\mu \mathrm{g} \mathrm{g}^{-1}\right)\end{array}$ & $\begin{array}{c}\text { Found } \\
\left(\mu \mathrm{g} \mathrm{g}^{-1}\right)\end{array}$ & $\begin{array}{c}\text { Pb } \\
\left(\mu \mathrm{g} \mathrm{g}^{-1}\right)\end{array}$ \\
\hline Pine Needles & $0.218 \pm 0.020$ & $0.233 \pm 0.004$ & $<0.8$ & $0.167 \pm 0.015$ \\
Peach Leaves & $<0.08$ & $0.026 \pm 0.003$ & $0.87 \pm 0.03$ & $0.81 \pm 0.03$ \\
Ginkgo Biloba & $<0.08$ & $0.020 \pm 0.001$ & $0.99 \pm 0.03$ & $0.99 \pm 0.07$ \\
\hline
\end{tabular}

TABLE IV

Results (Medium \pm SD, $\mathbf{n}=3$ ) for $\mathrm{Cd}$ and $\mathbf{P b}$ in Medicinal Plants Samples

\begin{tabular}{lrr}
\hline Samples & $\mathrm{Cd}\left(\mathrm{\mu g} \mathrm{g}^{-1}\right)$ & $\mathrm{Pb}\left(\mu \mathrm{g} \mathrm{g}^{-1}\right)$ \\
\hline Annona muricata & $<0.08$ & $<0.8$ \\
Baccharis trimera & $<0.08$ & $1.28 \pm 0.07$ \\
Echinodorus grandiflorus & $<0.08$ & $<0.8$ \\
Equisetum arvense & $0.34 \pm 0.01$ & $1.02 \pm 0.12$ \\
Matricaria chamomilla & $<0.08$ & $<0.8$ \\
Melissa officinalis & $0.19 \pm 0.01$ & $1.91 \pm 0.06$ \\
Mikania glomerata & $0.20 \pm 0.01$ & $<0.8$ \\
Panax ginseng & $<0.08$ & $<0.8$ \\
Peumus boldus & $<0.08$ & $<0.8$ \\
Pimpinela anisun & $<0.08$ & $1.06 \pm 0.19$ \\
\hline
\end{tabular}

Accuracy was checked for Cd and $\mathrm{Pb}$ determination in three plant SRMs (Table III). A paired $t$-test showed that the results found with the proposed GF-AAS method were in agreement with the certified values for $\mathrm{Cd}$ and $\mathrm{Pb}$ at the $95 \%$ confidence level.

The analysis of 10 medicinal plants (Table IV) presented concentrations in the range of $0.19-0.34 \mu \mathrm{g} \mathrm{g}^{-1}$ for $\mathrm{Cd}$ and 1.02-1.91 $\mu \mathrm{g} \mathrm{g}^{-1}$ for $\mathrm{Pb}$. These concentrations are comparable to media values $\left(0.5 \mu \mathrm{g} \mathrm{g}^{-1} \mathrm{Cd}\right.$ and $\left.1 \mu \mathrm{g} \mathrm{g}^{-1} \mathrm{~Pb}\right)$ usually found for medicinal plants (5).

\section{CONCLUSION}

This work presents a simple and fast method for the simultaneous determination of $\mathrm{Cd}$ and $\mathrm{Pb}$ in medicinal plants by GF-AAS using direct slurry sampling. Matrix effects did not impair aqueous solution calibra- tion. The relative standard deviations were $5.3 \%$ for $\mathrm{Cd}$ and $3.5 \%$ for $\mathrm{Pb}$. The LOD was $0.12 \mu \mathrm{g} \mathrm{L}^{-1}$ for $\mathrm{Cd}$ and $1.22 \mu \mathrm{g} \mathrm{L}^{-1}$ for $\mathrm{Pb}$. The proposed slurry sampling-based method did not require sample preparation with hazardous reagents, offers reduced risk of contamination or sample losses, less analysis time and waste, which are desirable characteristics of a clean analytical method.

\section{ACKNOWLEDGMENTS}

The authors thank the Fundação de Amparo à Pesquisa do Estado de São Paulo (FAPESP) for financial support. The authors are also grateful to Coordenação de Aperfeiçoamento de Pessoal de Nível Superior (CAPES) for the fellowship to F.M.F. and to Conselho Nacional de Desenvolvimento Científico e Tecnológico (CNPq) for researchship to J.A.G.N.
Received March 22, 2012.

\section{REFERENCES}

1. P. Kalny, Z. Fijałek, A. Daszczuk and P. Ostapczuk, Sci. Total Environ. 381, 99 (2007).

2. N.S. Chauhan, Medicinal and Aromatic Plants of Himachal Pradesh, 1st ed., Indus Pub., New Delhi, India (1999).

3. WHO, Quality control methods for medicinal plant materials. WHO, Geneva, Switzerland (2007).

4. S.S. Ražić, S.M. Dogo, L.J. Slavković, Microchem. J. 84, 93 (2006).

5. M.E. Farago, Plants and the Chemical Elements, 1st ed., Wiley-VHC, Weinheim, Germany (1994).

6. G.P.G. Freschi, C.S. Dakuzaku, M. Moraes, J.A. Nóbrega and J.A. Gomes Neto, Spectrochim. Acta, Part B 56, 1987 (2001).

7. N.J. Miller-Ihli, At. Spectrosc. 13, 1 (1992).

8. B. Welz and M. Sperling, Atomic Absorption Spectrometry, 3rd ed., Wiley-VHC, Weinheim, Germany (1999).

9. H. Chen, W. Hu, S. Li and M. Wang, Microchim. Acta 166, 133 (2008)

10. I. Karadjova and M. Karadjov, Fresenius J. Anal. Chem. 360, 246 (1998).

11. B. Ambrozini, V.R.A. Filho, S.R. Oliveira, L.V.S. Sacramento, J.A. Gomes Neto, Food Chem. 116, 1024 (2009).

12. W. Slavin, D.C. Manning, G.R. Carnrick, At. Spectrosc. 2, 137 (1981).

13. G.P.G. Freschi, C.D. Freschi, S.R. Oliveira and J.A. Gomes Neto, At. Spectrosc. 27, 179 (2006).

14. L.A. Currie, Anal. Chim. Acta 391, 105 (1999) 